\title{
The influence of various common ions on the slaking of some South African limes
}

\author{
JH Potgieter 1 , SS Potgieter ${ }^{2 *}$, CA Strydom ${ }^{3}$ and O Gheevarhese ${ }^{4}$ \\ ${ }^{1}$ Department of Chemical \& Metallurgical Engineering, Technikon Pretoria, Private Bag X680, Pretoria 0001, South Africa \\ ${ }^{2}$ Department of Chemistry \& Physics, Technikon Pretoria, Private Bag X680, Pretoria 0001, South Africa \\ ${ }^{3}$ Department of Chemistry, University of Pretoria, Pretoria 0001, South Africa \\ ${ }^{4}$ Department of Chemistry, Medunsa, Pretoria 0204, South Africa
}

\begin{abstract}
The rate of transformation from $\mathrm{CaO}$ to $\mathrm{Ca}(\mathrm{OH})_{2}$ during the slaking process is influenced by a number of factors. In this investigation the effects of common ions normally encountered in the slaking water were investigated. It was found that chloride and nitrate ions enhanced the slaking rate, while carbonate, sulphate and phosphate ions retarded the hydration of various limes used in the investigation. The increases and decreases in the degree of hydration correlate with the solubilities of the anions forming more soluble compounds than $\mathrm{Ca}(\mathrm{OH})_{2}$, as well as the solubility constants of the anions that formed less soluble compounds than the hydrated lime. The geological origin of the lime also influenced the slaking of the limes.
\end{abstract}

Keywords: lime, slaking, geological origin, accelerating anions, decelerating anions

\section{Introduction}

Lime is one of the most important industrial chemicals and its slaking from the quicklime $(\mathrm{CaO})$ form to the hydrated lime $\left(\mathrm{Ca}(\mathrm{OH})_{2}\right)$ species is of importance in a number of practical applications, such as potable water treatment, neutralisation of acidic effluents and flue gas desulphurisation, to name but a few. The rate of transformation from $\mathrm{CaO}$ to $\mathrm{Ca}(\mathrm{OH})_{2}$ during the slaking process is influenced by a number of factors, for example the production and storage conditions of the lime (Potgieter et al., 2002) the water and material composition (Gheevarhese et al., 2002; Potgieter et al., 2003a) and calcination temperature (Moropoulou et al., 2001).

Recently the authors described the effect of different agitation methods on the hydration rate of lime (Potgieter et al., 2003b) and concluded that this, together with the geological origin of the lime, greatly affects the amount of slaking occurring in each particular case.

This investigation further explores the influence of common ions, which can be encountered in water used for slaking quicklime, on the hydration rate of various limes. An ultrasonic agitation procedure was employed, as it is a faster way of slaking lime than the mechanical method used in the previous investigations by the group.

\section{Experimental procedure}

The experimental detail and set-up have been described comprehensively in previous papers dealing with this topic (Gheevarhese et al., 2002; Potgieter et al., 2003b). In this investigation ultrasonic agitation was used to induce hydration of the various lime samples in the different solutions of interests. The chemical compositions of the various lime samples are given in Table 1. A description of their sources of origin can be found in previous work described in

\footnotetext{
* To whom all correspondence should be addressed. 표+2712 318 6368; fax: +2712 318 6286; e-mail: potgieters@techpta. ac.za
}

\begin{tabular}{|c|c|c|c|}
\hline \multicolumn{4}{|c|}{$\begin{array}{l}\text { TABLE } 1 \\
\begin{array}{c}\text { Chemical composition of the various limestones } \\
\text { investigated }\end{array}\end{array}$} \\
\hline $\begin{array}{l}\text { Element } \\
\text { expressed } \\
\text { as relevant } \\
\text { oxide }\end{array}$ & $\begin{array}{l}\text { Pienaars- } \\
\text { river } \\
\text { limestone } \\
\%(\mathrm{~m} / \mathrm{m})\end{array}$ & $\begin{array}{l}\text { Lime } \\
\text { Acres } \\
\text { limestone } \\
\%(\mathrm{~m} / \mathrm{m})\end{array}$ & $\begin{array}{l}\text { Beeste- } \\
\text { kraal } \\
\text { limestone } \\
\%(\mathrm{~m} / \mathrm{m})\end{array}$ \\
\hline $\mathrm{SiO}_{2}$ & 18.95 & 0.54 & 4.42 \\
\hline $\mathrm{Al}_{2} \mathrm{O}_{3}^{2}$ & 2.40 & 0.26 & 0.80 \\
\hline $\mathrm{Fe}_{2}^{2} \mathrm{O}_{3}^{3}$ & 1.12 & 0.05 & 0.28 \\
\hline $\mathrm{MnO}$ & 0.08 & 0.54 & 0.86 \\
\hline $\mathrm{TiO}_{2}$ & 0.13 & 0.01 & 0.02 \\
\hline $\mathrm{CaO}^{2}$ & 42.37 & 55.34 & 49.47 \\
\hline $\mathrm{MgO}$ & 1.23 & 0.80 & 3.30 \\
\hline $\mathrm{P}_{2} \mathrm{O}_{5}$ & $<0.01$ & $<0.01$ & $<0.01$ \\
\hline $\mathrm{K}_{2}^{2} \mathrm{O}$ & 0.30 & 0.04 & 0.40 \\
\hline $\mathrm{Na}_{2} \mathrm{O}$ & 0.17 & 0.14 & 0.05 \\
\hline LOI & 34.09 & 42.99 & 40.93 \\
\hline TOTAL & 100.84 & 100.71 & 100.53 \\
\hline
\end{tabular}

the literature (Gheevarhese et al., 2002). All slaking percentages were normalised to the total amount of available lime contained in each limestone after calcining.

\section{Results and discussion}

The effect of a $1 \mathrm{M} \mathrm{NaCl}$ and a $1 \mathrm{M} \mathrm{NaNO}_{3}$ addition to the slaking water on the hydration rate of pure lime and three other different natural limes is shown schematically in Figs. 1 to 4 . It can clearly be seen from all the curves in Figs. 1 to 4 that the nitrate enhanced the slaking rate in the initial stage of the hydration reaction. However, the degree of hydration becomes practically the same from 
Pure Lime

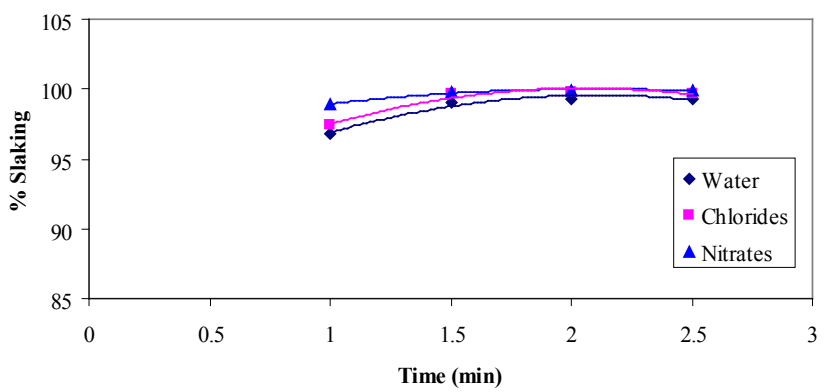

Figure 1

The effect of chloride and nitrate ions on the hydration rate of pure calcium oxide

Lime Acres

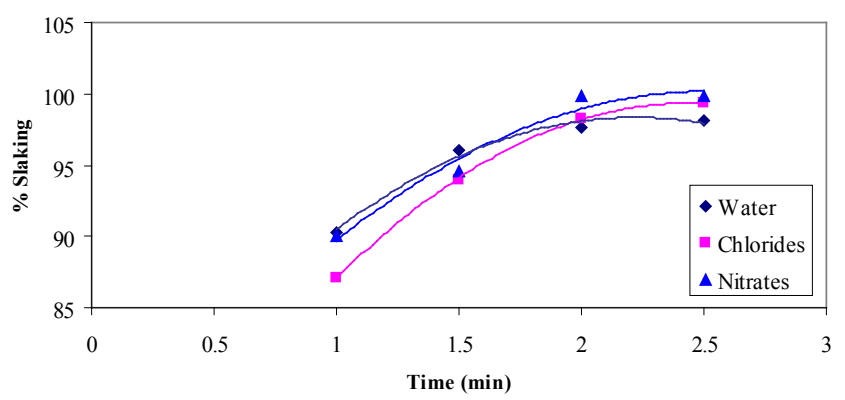

Figure 2

The effect of chloride and nitrate ions on the hydration rate of Lime Acres lime

\section{Beestekraal}

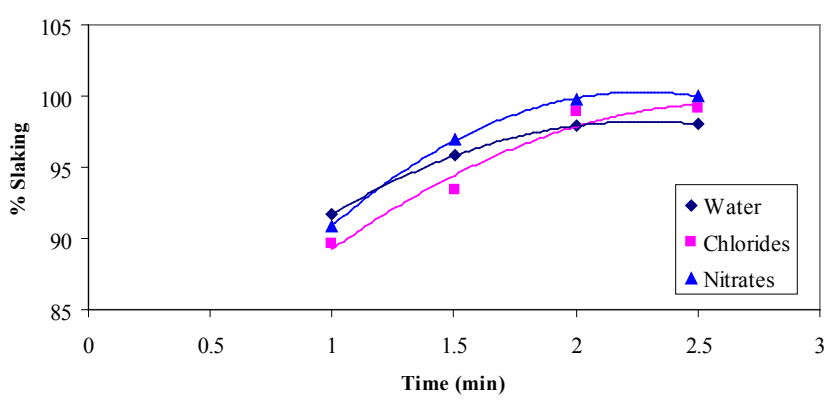

Figure 3

The effect of chloride and nitrate ions on the hydration rate of Beestekraal lime

Pienaarsriver

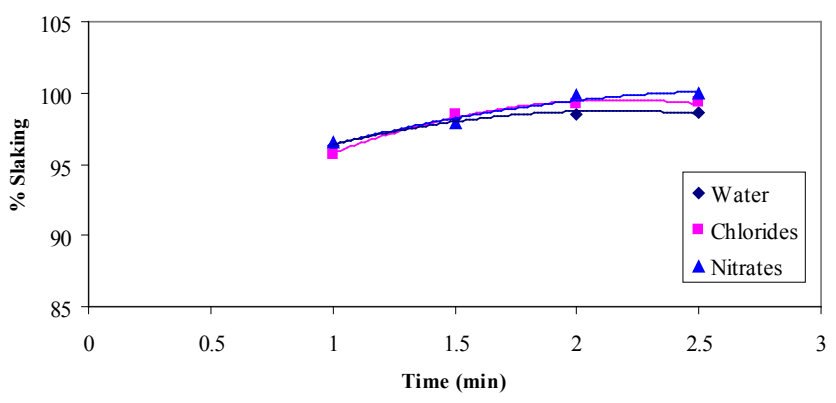

Figure 4

The effect of chloride and nitrate ions on the hydration rate of Pienaarsriver lime

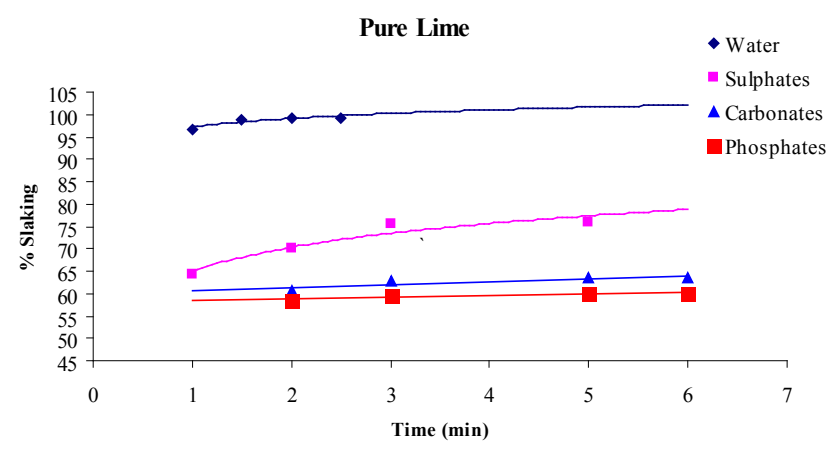

Figure 5

The effect of sulphate, carbonate and phosphate ions on the hydration rate of pure calcium oxide

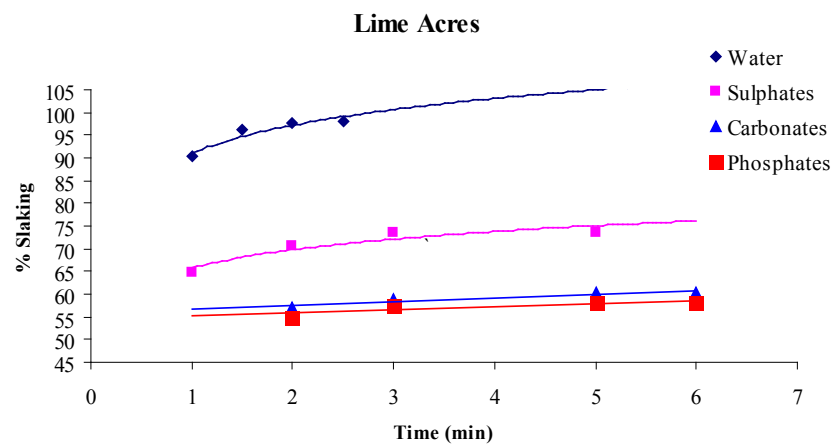

Figure 6

The effect of sulphate, carbonate and phosphate ions on the hydration rate of Lime Acres lime

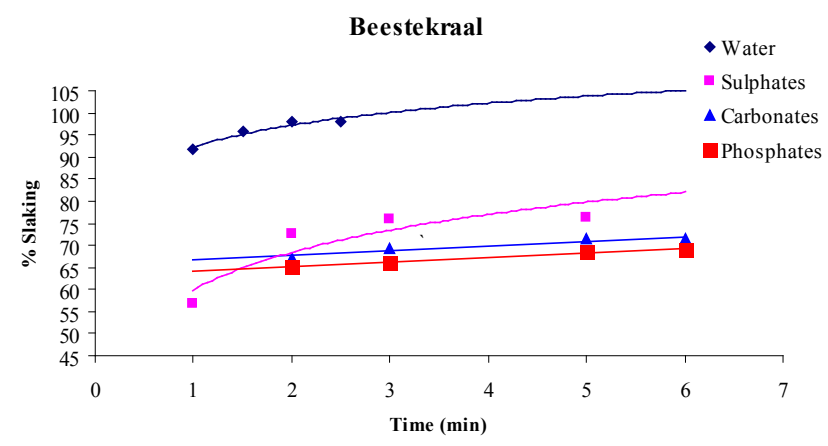

Figure 7

The effect of sulphate, carbonate and phosphate ions on the hydration rate of Beestekraal lime

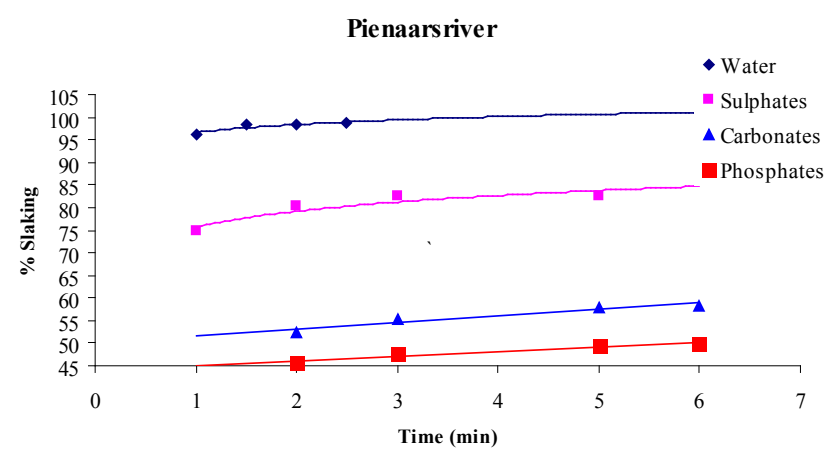

Figure 8

The effect of sulphate, carbonate and phosphate ions on the hydration rate of Pienaarsriver lime

Available on website http://www.wrc.org.za 
Figure 9 ions on the hydration rate of various limes

Figure 10

The effect of carbonate ions on the hydration rate of various limes
The effect of nitrate
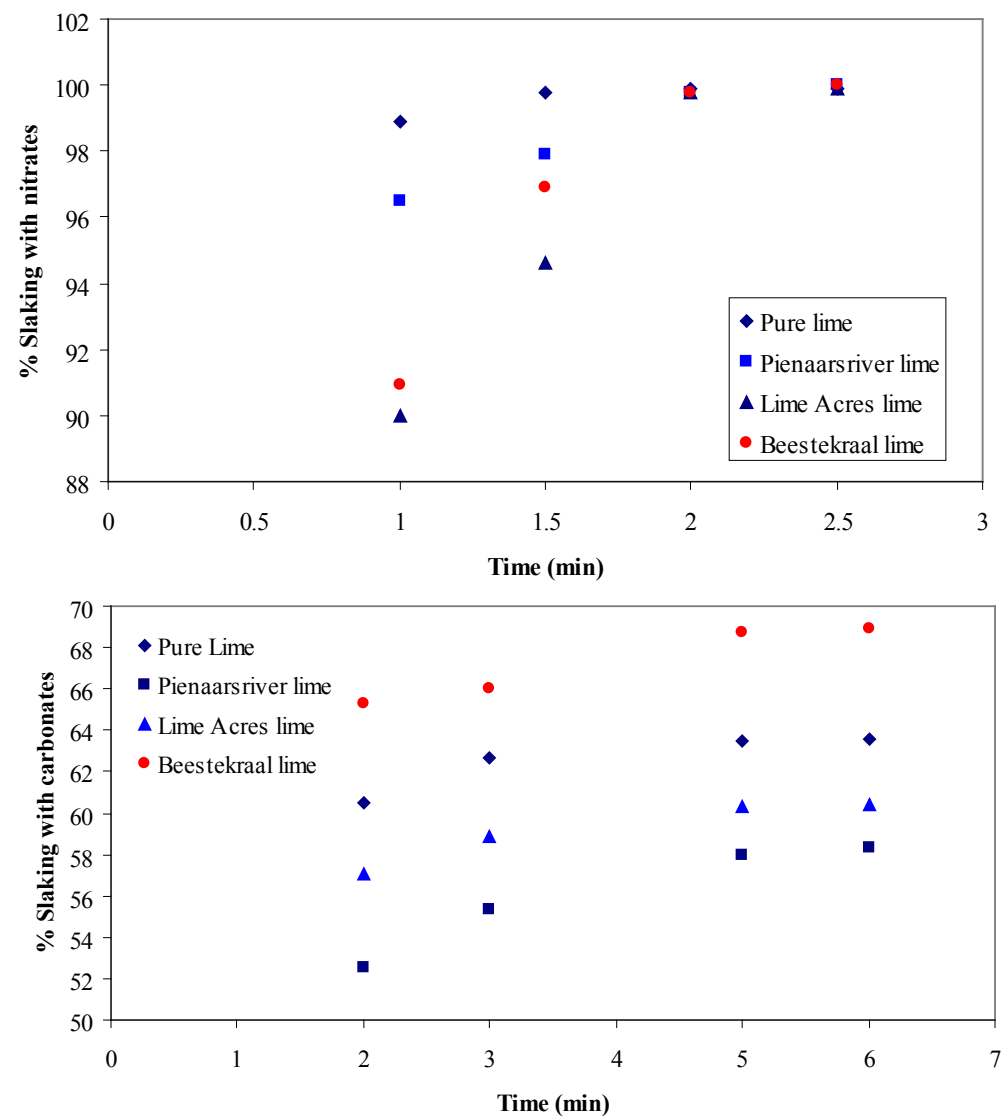

added to the solution. In cases where the added anion decreased the solubility of the lime, the sequence was generally:

Beestekraal $>$ Pure lime $>$ Lime Acres / Pienaarsriver

\section{Conclusions}

The following conclusions can be drawn from this investigation:

- The hydration rate of lime is enhanced upon the addition of anions that form more soluble calcium compounds than lime to the slaking water.

- The initial enhancement of the slaking rate of lime is greater for nitrate than for chloride, which is in agreement with the fact that calcium nitrate has a higher solubility in water than calcium chloride.

- The hydration rate of lime is decreased upon the addition of anions that form less soluble calcium compounds than lime to the slaking water.

- The decrease in the degree of hydration increases in the order of $\mathrm{SO}_{4}^{2-}<\mathrm{CO}_{3}^{2-}<\mathrm{PO}_{4}^{3-}$, which is in agreement with the decrease in the solubilities of the corresponding calcium compounds with these anions.

- The increase in lime slaking by $\mathrm{Cl}^{-}$and $\mathrm{NO}_{3}^{-}$, as well as the decrease caused by $\mathrm{SO}_{4}^{2-}, \mathrm{CO}_{3}{ }^{2-}$ and $\mathrm{PO}_{4}^{3--}$ ions have been quantified and this could assist in practical applications of lime in industry.

\section{Acknowledgements}

arole in the observed slaking behaviour. In this investigation, it was found that the hydration occurred to a greater degree in the sequence:

\section{Pure lime $>$ Pienaarsriver $>$ Lime Acres / Beestekraal}

wherever an anion that enhances the solubility of the lime was
The National Research Foundation (NRF), the Technikon of Pretoria, the University of Pretoria and the Medical University of South Africa (Medunsa) are gratefully acknowledged for financial assistance. 


\section{References}

CRC HANDBOOK OF CHEMISTRY \& PHYSICS (1980) CRC Press Inc. Boca Raton, Florida, USA. B220: B64-67.

GHEEVARHESEO, STRYDOM CA, POTGIETER JH and POTGIETER SS (2002) The influence of chloride and sulphate ions on the slaking rate of lime derived from different limestone deposits in South Africa. Water SA 28 (1) 45-48.

MOROPOULOU A, BAKOLAS A and AGGELAKOPOULOU E (2001) The effects of limestone characteristics and calcination temperature to the reactivity of the quicklime. Cem. \& Concr. Res. 31 633-639.
POTGIETER JH, POTGIETER SS, MOJA SJ and MULABA-BAFUBIANDI AF (2002) An empirical study of factors influencing lime slaking: Part I. Production and storage conditions. Min. Eng. 15 201-203.

POTGIETER JH, POTGIETER SS and DE WAALD (2003a) An empirical study of factors influencing lime slaking: Part II. Influence of material and water composition. Water SA 29 (2) 157-160.

POTGIETER SS, GHEEVARHESE O and STRYDOM CA (2003b) The effect of ultrasonic energy on the slaking of lime. Min. Eng. 16 (8) 767-770.

ZOLTEK J (Jr) (1974) Phosphorus removal by orthophosphate nucleation. J. Water Pollut. Control Fed. 46 (11) 2498-2519. 